\title{
Als2 silencing affects the expression of two NF-kB targeted genes via UXT in adult mouse primary spinal motor neuron culture
}

\author{
Als2'nin susturulmasının NF-kB hedefli iki genin ekspresyonlarına UXT \\ üzerinden etkisinin yetişkin fare primer spinal motor nöron kültüründe
} araştırılması

M. Beyza ÇETIN OZANSOY ${ }^{\oplus}$, Mehmet OZANSOY ${ }^{2} \odot$

\section{ABSTRACT}

Aim: Amyotrophic Lateral Sclerosis (ALS) is a neurodegenerative disorder affecting motor neurons. Als 2 is one of the genes that cause $A L S$, and its mutations leads to loss of function in alsin protein. The interaction between alsin, and UXT protein has been documented in vitro. UXT is a cofactor in NF-KB pathway. Our aim is to investigate the potential effect of silencing of Als2 on the activity of NF-KB pathway in primary motor neurons.

Method: Neurons were demonstrated immunocytochemically via reaction with anti-ChAT and anti-BIII tubulin primary antibodies in spinal motor neuron culture of adult BalbC mice. Als2 was silenced using RNAi method and confirmed by qRT-PCR. Expressions of UXT, A20 and IL8 in motor neurons where Als2 was silenced were determined by qRT-PCR. TNF- $\alpha$, an NF-KB activator, was also applied and alterations in the expressions of A20 and IL8 were measured using qRT-PCR.

Results: Expressions of Als2, UXT, and IL8 were reduced by $74.3 \%$, $40 \%$, and $84.4 \%$ by RNAi in immunocytochemically characterized spinal motor neurons (for all, $p<0.0001$ ). whereas A20 expression increased by $65 \%(p<0.0001)$. When TNF- $\alpha$ was applied to neurons, IL 8 expression increased by 17-fold, but the increase in A20 was only $29.5 \%$.

Conclusion: In the light of these findings, correlation between expressions of Als2 and UXT has been proven. Decreases in the levels of Als 2 and UXT cause a reduction in IL8 expression, whereas expression of A20 increases. This indicates that silencing of Als2 might reduce inflammatory response while activating pro-apoptotic signals. When NF-KB pathway has been activated by TNF- $\alpha$, a considerable increase in IL8 has been observed. Thus for the first time a functional link between Als2, and NF-KB pathway over UXT has been confirmed in primary spinal motor neuron culture, and the role played by key molecules as IL8, and A20 on NF-kB pathways has been demonstrated.

Keywords: Als2, spinal motor neuron, UXT, IL8, A20
Öz

Amaç: Amiyotrofik Lateral Skleroz (ALS) motor nöronları etkileyen nörodejeneratif bir hastalıktır. Als2, ALS'ye neden olan genlerden biri olup, mutasyonları alsin proteininde islev kaybına yol açar. Alsin ile UXT proteininin etkileştiği in vitro olarak gösterilmiştir. UXT NF-KB yolağında bir kofaktördür. Çalışmadaki amacımız, Als2 geninin susturulmasının NF-kB yolağı aktivitesine olan olası etkisinin primer spinal motor nöronlarda araştırılmasıdır.

Yöntem: Yetişkin BalbC fare spinal motor nöron kültüründe, nöronlar anti-ChAT ve anti-bIII tubulin primer antikorları ile immünositokimyasal olarak gösterildi, Als2 geni RNAi yöntemi ile susturuldu ve qRT$P C R$ ile doğrulandı. Als2'nin susturulduğu motor nöronlardaki UXT, A20 ve IL8 gen ekspresyonları qRT-PCR ile belirlendi. NF-KB aktivatörü olan TNF- $\alpha$ kullanılarak A20 ve IL8 ekspresyonlarındaki değişim qRTPCR ile ölçüldü.

Bulgular: Immünositokimyasal olarak gösterilen spinal motor nöronlarda RNAi ile Als2 gen ekspresyonu \%74,3 oranında azaldığı ( $p<0,0001)$ ve UXT ekspresyonunun \%40 düştügü saptandı $(p<0,0001)$. IL8 seviyesinin $\% 84,4$ azaldığı, ancak $A 20$ seviyesinin $\% 65$ arttığı gözlendi $(p<0,0001)$. Nöronlara TNF- $\alpha$ uygulandığında IL8 ekspresyonunun 17 kat yükseldiği, ancak A20 ekspresyonunun yalnızca \%29,5 arttığı saptandı.

Sonuç: Bu bulgular ışığında Als2 ile UXT arasındaki gen ekspresyonu seviyesindeki korelasyonun sağlaması yapılmıştır. Als2 ve UXT seviyesindeki düşüş IL8 seviyesini azaltırken A20'yi yükseltmektedir. Bu veriler Als2'nin susturulmasının enflamatuar yanıtı azaltırken pro-apoptotik sinyalleri A20 üzerinden tetikleyebileceğini düşündürmektedir. TNF- $\alpha$ kullanılarak NF-KB yolağı aktive edildiğinde, IL8 artışı üzerinden gerçekleşen enflamatuvar bir yanıt görülmektedir. Böylece Als2 ile NF-KB yolağı arasındaki işlevsel bağlantının UXT üzerinden gerçekleștiği ilk kez primer spinal motor nöron kültüründe doğrulanmış olup, IL8 ve A20 gibi NF-KB yolağındaki kilit moleküllerin bu bağlamda rol oynadığı gösterilmiştir.

Anahtar kelimeler: Als2, spinal motor nöron, UXT, IL8, A20

Received: 15.05 .2018

Accepted: 01.08.2018

${ }^{1}$ Istanbul Medipol University, School of Medicine, Dept. of Physiology, Istanbul, Turkey

${ }^{2}$ Istanbul Medipol University, International School of Medicine, Dept. of Physiology, Istanbul, Turkey

Yazışma adresi: Mehmet Ozansoy, Istanbul Medipol University, International School of Medicine, Dept. of Physiology, Istanbul, Turkey

e-mail: mozansoy@medipol.edu.tr

Yazarların ORCiD bilgileri:

M.B.Ç.O. 0000-0003-4228-4577, M.O. 0000-0002-1079-8832 


\section{INTRODUCTION}

Amyotrophic Lateral Sclerosis (ALS) is a neurodegenerative disorder characterized by the selective loss of motor neurons. Degeneration of motor neurons leads to progressive weakness, muscle atrophy and death that generally ensue within 2-5 years after diagnosis. ALS has a yearly prevalence of $2 / 100,000$ and a lifetime risk of $1 / 800$. Approximately $10 \%$ of the cases have hereditary transmission and the rest is sporadic ${ }^{1}$. Although several genes and chromosomal loci have been described for the cause of familial ALS (FALS), the underlying molecular mechanism still remains to be identified.

Recent findings have shown the involvement of various molecular pathologies such as endoplasmic reticulum stress, excitotoxicity, oxidative stress, neuronal inflammation, axonal transport dysfunctions in the progressive pathology of $\mathrm{ALS}^{2-4}$.

Als2 (alsin), one of the causative genes of ALS, resides on chromosome 2q33.1; its mutations lead to a premature termination of translation or to amino acid substitution, causing an autosomal recessive juvenile onset ALS through the loss of function of the alsin protein. The $184 \mathrm{kD}$ Als2 protein (alsin) consists of three putative Guanine Nucleotide Exchange Factor (GEF) domains; the regulator of chromosome condensation 1 (RCC1) domain, the Dbl-homology/Pleckstrinhomology (DH/PH) domain and the Vacuolar Protein Sorting 9 (VPS9) domain. In addition to these three domains, there are eight consecutive Membrane Occupation and Recognition Nexus (MORN) motifs between DH/PH and VPS9 domains ${ }^{5,6}$.

Current research have shown that alsin might have a role in endosomal trafficking through its VPS9 domain, and that it could also function in intracellular signalling pathways with its $\mathrm{DH} / \mathrm{PH}$ domain ${ }^{7}$. In relation with this data, alsin plays a regulatory role in autophagy-endolysosomal system ${ }^{8}$.

It is also known that alsin expression has a neuroprotective role when mutant SOD1, the major gene lea- ding to ALS, is expressed in the same motor neurons ${ }^{9-}$ 11 .

Enunlu et al previously showed that the Ubiquitously Expressed Transcript protein (UXT) is a novel interacting partner of Als $2^{12}$. The UXT gene is located on chromosome Xp11.23-p11.22 in humans and its protein is approximately $18 \mathrm{kD}$. The UXT protein is a member of $\alpha$-class prefoldin-like family proteins. It is known that UXT acts as a coregulator in the androgen stimulated transcription via binding to the Androgen Receptor $(A R)^{13}$. It has also been demonstrated that UXT is a cofactor in the NF-KB enhancesome complex. NF-kB mediates the expression of crucial genes playing roles in development, immunity and inflammation. Silencing of the expression of UXT directly affects the NF-KB activation and decreases the expression of NF-KB-dependent genes such as IL8 and A2014.

In this study we silenced Als2 gene in primary spinal motor neuron culture and aim to investigate the changes in the expression levels of UXT and NF-KB activated genes, IL8 and A20.

\section{MATERIALS and METHODS}

\section{Primary Spinal Motor Neuron Culture}

Our study was approved by the local Experimental Animals Ethics Committee, and the experiments were in compliance with the international guidelines on the ethical use of animals.

In this study 15 6-week old adult female Balb-C mice were used.

Primary spinal motor neuron culture was performed according to the protocol in Bektas et al. ${ }^{14}$. Briefly, the mice were sacrificed under anaesthesia, induced by intramuscular administration of ketamine at $60 \mathrm{mg} /$ kg (Ketalar; Eczacibasi Ilac Sanayi, Levent, Istanbul, Turkey) and xylazine hydrochloride at $6 \mathrm{mg} / \mathrm{kg}$ (Rompun; Bayer Ilac Sanayi, Sisli, İstanbul, Turkey). Spinal cord was dissected out and placed onto Leibovitz's Medium (L-15, cat. no: L5520, SIGMA, USA). The an- 
M.B. Çetin Ozansoy ve M. Ozansoy, Als2 silencing affects the expression of two NF-KB targeted genes via UXT in adult mouse primary spinal motor neuron culture

terior part of the cord was chopped up into small pieces and these pieces were transferred into Neurobasal Medium A (cat. no: 10888022, ThermoFisher, USA) containing 2 mM Glutamax (cat. no: 35050061, ThermoFisher, USA), $100 \mathrm{U}$ penicillin, $100 \mathrm{mg}$ streptomycin, 250 ng amphotericin (cat. no: A5955, SIGMA, USA), 6U papain (cat.no: P4762, SIGMA, USA) and 2\% (v/v) B-27 (cat. no: 17504044, ThermoFisher, USA). The tissue pieces were incubated at $+4 \mathrm{C}^{\circ}$ for 30 minutes and then they were agitated on an agitator at $+4 \mathrm{C}^{\circ}$ for 15 minutes. For mechanical dissociation trituration was performed for 7 minutes.

In order to isolate spinal motor neurons selectively, Percoll gradient centrifugation was used, and mechanically dissociated cell suspension was centrifuged at 3,000 rpm for 25 minutes at $+4 \mathrm{C}^{\circ}$. Isolated spinal motor neurons was spinned down at $700 \mathrm{rpm}$ for 3 minutes at $+4 C^{\circ}$, pelleted cells were resuspended by adding Neurobasal A medium with the same composition as described above. Cells were cultured on 35-mm culture dishes coated with poly-D-lysine and incubated in a cell culture incubator at $37 \mathrm{C}^{\circ}$ with $5 \% \mathrm{CO}_{2}$ for 2 hours. Then, the culture medium was replaced with L-15 containing $2 \mathrm{mM}$ Glutamax (cat. no: 35050061, ThermoFisher, USA), 100 U penicillin, $100 \mathrm{mg}$ streptomysin, $250 \mathrm{ng}$ amphotericin (cat. no: A5955, SIGMA, USA) and 2\% (v/v) B-27 (cat. no: 17504044, ThermoFisher, USA) and the cells were incubated at $+4 \mathrm{C}^{\circ}$ for 72 hours. At the end of the cold incubation period, the culture medium was replaced with Neurobasal A medium containing abovementioned reagents and spinal motor neurons were incubated at $37 \mathrm{C}^{\circ}$ with $5 \% \mathrm{CO}_{2}$ for further experiments.

\section{Plasmid constructs}

In order to generate short hairpin RNA (shRNA) specific for the $\mathrm{DH} / \mathrm{PH}$ region of the Als2 transcript, we used the pSilencer ${ }^{\mathrm{TM}}$ 2.1-U6 (Ambion, ABI, USA) vector. The following oligos were annealed and cloned into the vector according to the manufacturer's instructions.
Als2(KD)F:5'GATCCATGACGGATTCCTTGAGGATTCAAG AGATCCTCAAGGAATCCGTCATTTTTTTGGAAA 3' Als2(KD)R:5'AGCTTTTCCAAAAAAATGACGGATTCCTTG AGGATCTCTTGAATCCTCAAGGAATCCGTCATG 3'

\section{Immunocytochemistry}

Immunocytochemical analysis was done with motor neuron marker primary antibodies, against choline acetyltransferase (ChAT) (cat. no: ab181023, Abcam, UK) and anti- $\beta$ III tubulin antibody (cat. no: ab18207, Abcam, UK) in order to prove that cultured cells were spinal motor neurons. For this analysis neurons were fixed in $4 \%(\mathrm{v} / \mathrm{v})$ paraformaldehyde and then permeabilization/blocking solution containing $0.1 \%$ Triton-X-100 (cat. no: T8787, SIGMA, USA), 3\% (v/v) bovine serum albumin, $1 \%$ chicken serum (cat. no: 16110082, GIBCO, USA) was applied for 30 minutes at $+4 \mathrm{C}^{\circ}$. Then, cells were incubated with anti-ChAT or anti- $\beta$ III tubulin antibodies overnight at $+4 \mathrm{C}^{\circ}$. Next day secondary antibodies (cat. no: ab150073, Abcam, UK; cat. no: ab150108, Abcam, UK) were applied and the neuron were visualized by using laser confocal microscopy.

\section{Als2 Silencing}

Cultured primary spinal motor neurons were transfected with $2 \mu \mathrm{g}$ expression vector pSilencerTM2.1U6 (Ambion, $A B I, U S A)$, containing shRNA, specific for the Als2 transcript or control vector having scrambled shRNA sequence provided by the manufacturer in FuGENE HD Transfection Reagent (Roche, Germany). After 72 hours of transfection, the Als 2 gene expression was measured.

In a second experimental setting Tumour Necrosis Factor- $\alpha$ (TNF- $\alpha$, cat. no: T7539, SIGMA, USA) was applied to the motor neurons in Als2 knocked-down background.

\section{Quantitative RT-PCR (qRT-PCR)}

In order to determine the expression levels of Als2, UXT, IL8 and A20, total RNA was isolated from the 
cells by using the High Pure RNA Isolation Kit (Roche, Germany). QRT-PCR was performed using the iTaq Universal SYBR Green One-Step Kit (cat. no: 1725150, Bio-Rad, USA) and CFX96 Touch Real-Time PCR Detection System (Bio-Rad, USA). The following primers were used:

Als2F: 5' TCCAGTTCTTGCTATGAGTCTCT 3'

Als2R: 5' GGAATCCGTCATTTTCCCAGG 3'

UxtF: 5' TTGGGCTGTAACTTCTTCGTTG 3'

UxtR: 5' AGGAGAGAACTCTTTCGGTCAA 3'

IL8F: 5' ATGCCCTCTATTCTGCCAGAT 3'

IL8R: 5' GTGCTCCGGTTGTATAAGATGAC 3'

A20F: 5' TGGGTGCCCTTTTACTTTGAAT 3'

A20R: 5' GCTCTGCTGTAGTCCTTTTTGAAA 3'

ß-ActinF: 5' GGCTGTATTCCCCTCCATCG 3'

B-ActinR: 5' CCAGTTGGTAACAATGCCATGT 3'
QRT-PCR experiments were repeated at least three times independently and the $\beta$-Actin transcript level was used to normalize the data according to $\Delta \Delta \mathrm{Cq}$ method. In order to evaluate the normalized data statistically, Student-t test in the Statistical Package for Social Sciences (SPSS) Version 10.0 software was used. When the $p$ values were less than 0.05 , the difference between the experimental values and the control values were considered statistically significant. In order to test the normality of data, AndersonDarling ( $A D)$ test was used. It is known that AD statistics is one of the best for detecting departure from normality, even when used in small sample sizes $(n \leq 25)$. So the $p$ value found was greater than 0.05 , indicating the normality of the normalized data.

\section{RESULTS}

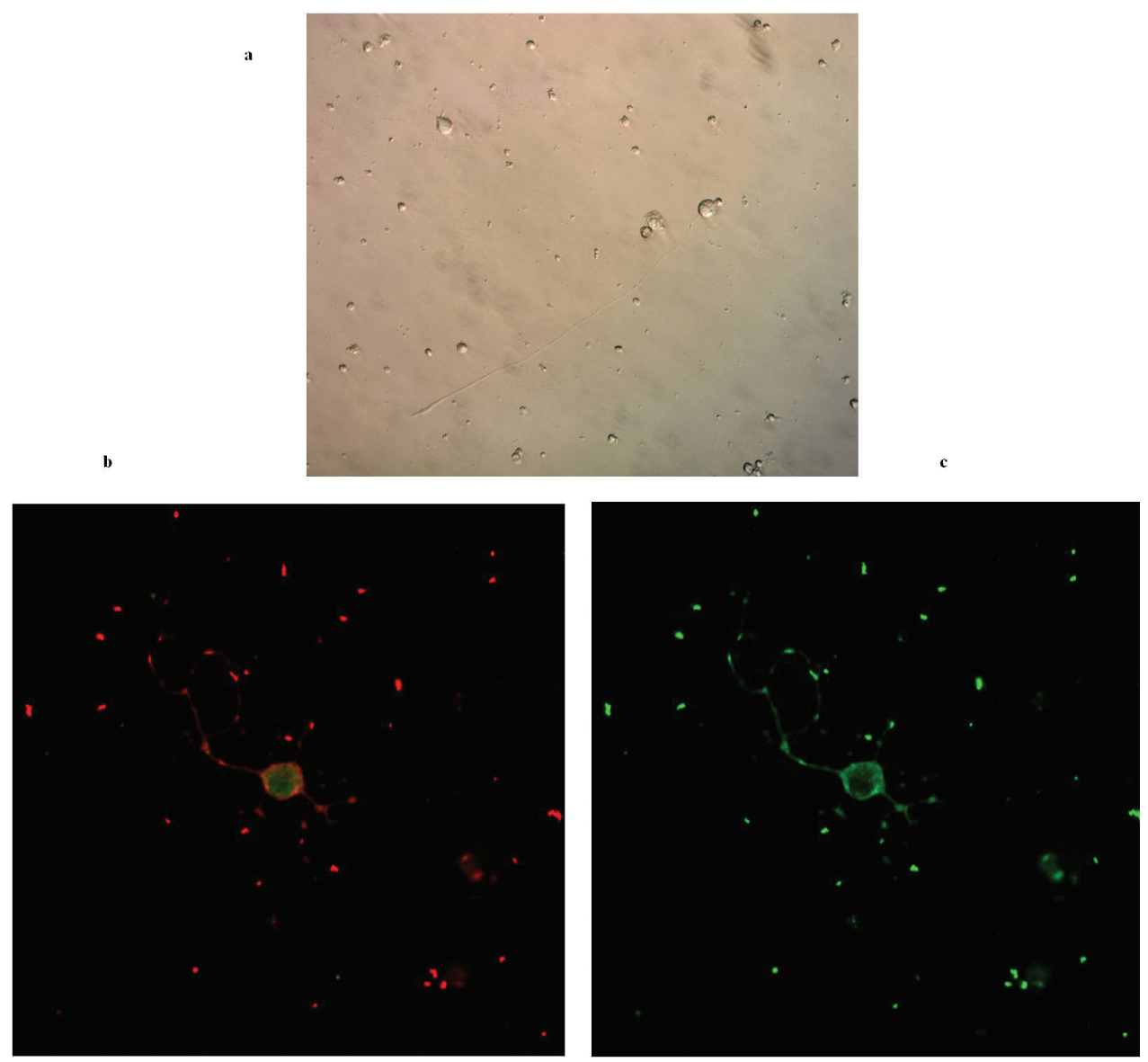

Figure 1. Imaging of cultured primary spinal motor neurons. (a) Light microscopy showing a spinal motor neuron with its prominent growth cone (40X); (b) Laser confocal microscopy imaging of spinal motor neurons with anti-ChAT antibody labeling (40X with oil immersion); (c) Laser confocal microscopy imaging of spinal motor neurons with anti- $\beta$ III tubulin antibody labeling (40X with oil immersion) 
M.B. Çetin Ozansoy ve M. Ozansoy, Als2 silencing affects the expression of two NF-KB targeted genes via UXT in adult mouse primary spinal motor neuron culture

\section{Imaging of Primary Spinal Motor Neurons}

Primary spinal motor neurons were visualized on the fifth day of culture by light and laser confocal microscopy. Figure 1a showed a spinal motor neuron with its prominent growth cone by light microscopy. These motor neurons were also labelled with anti-ChAT and anti- $\beta$ III tubulin antibodies and they were visualized

a

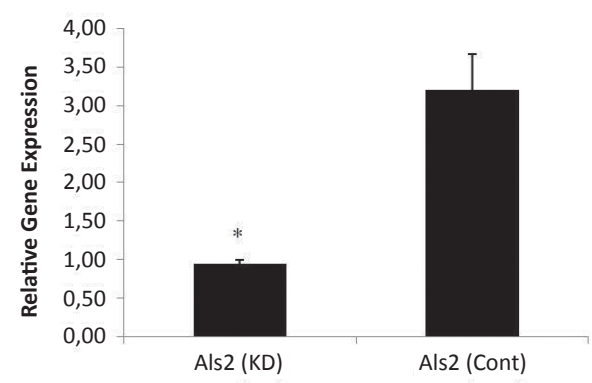

by laser confocal microscopy in order to confirm that they were motor neurons (Fig. $1 \mathrm{~b}$ and c).

Alterations of UXT Expression when Als2 expression
was changed

After primary spinal motor neurons were transfected with pSilencer ${ }^{\mathrm{TM}}$ 2.1-U6 (Ambion, $\mathrm{ABI}$, USA), containing shRNA specific for the $\mathrm{DH} / \mathrm{PH}$ region of the

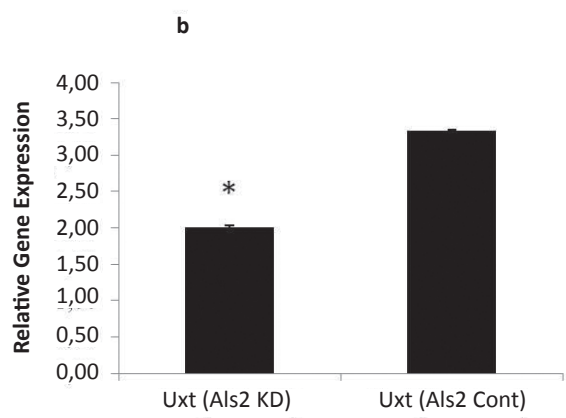

Figure 2. Data of gene expression alterations of Als2 and UXT. (a) Relative gene expression of Als2 after RNAi (Als2 KD) with respect to control (Als2 Cont.); (b) Relative gene expression of UXT in silenced Als2 background (Uxt Als2 KD) with respect to control (Uxt Als2 Cont). (*) symbol indicates that $p<0.0001$.
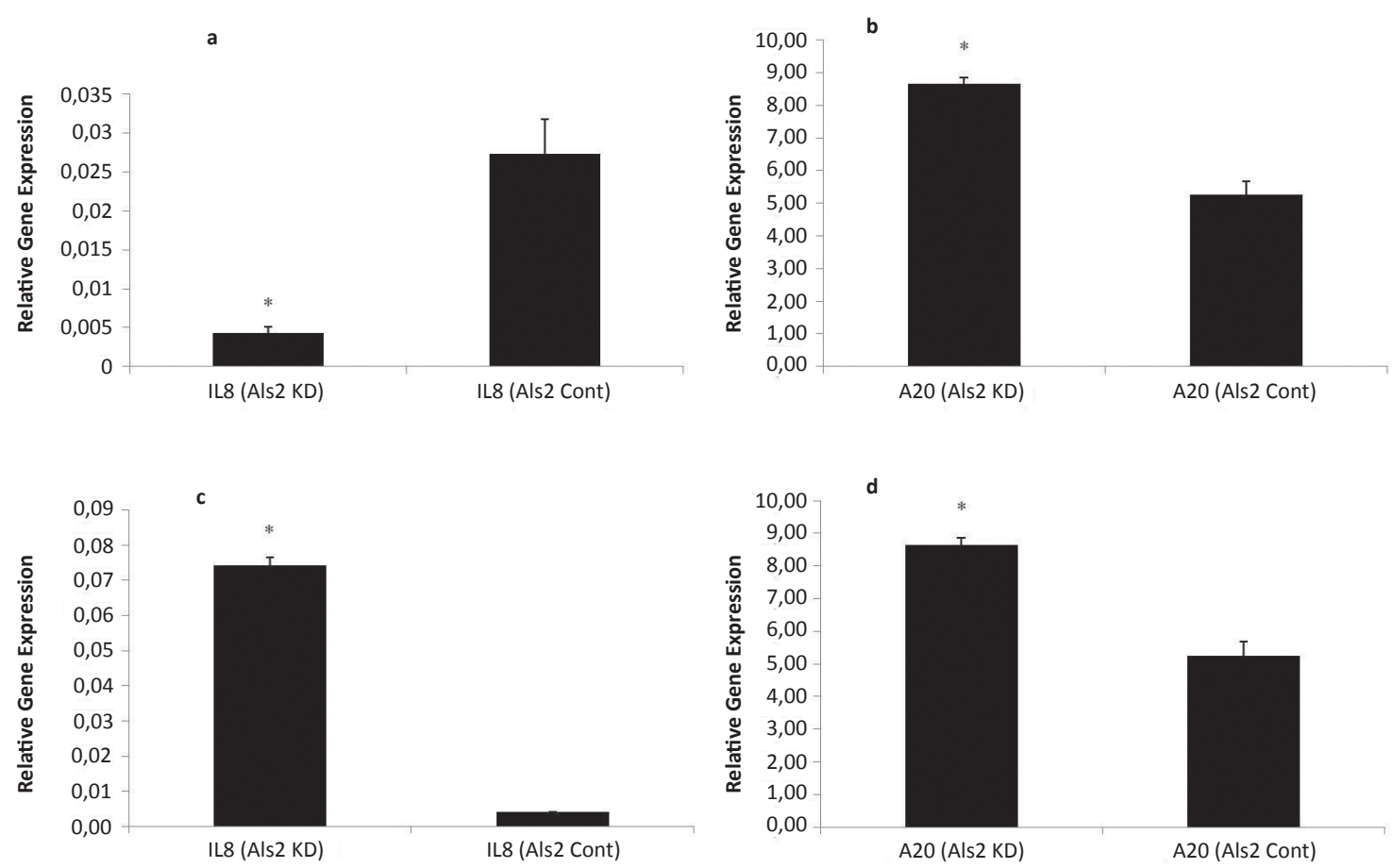

Figure 3. Gene expression changes of IL8 and A20. (a) Relative gene expression of IL8 in Als2 knocked-down neurons (IL8 Als2 KD) with respect to control (IL8 Als2 Cont.); (b) Relative gene expression of A20 in silenced Als2 background (A20 Als2 KD) with respect to control (A20 Als2 Cont); (c) Relative gene expression of IL8 after TNF- $\alpha$ application in Als2 knocked-down neurons (IL8 Als2 KD) with respect to control (IL8 Als2 Cont.); (d) Relative gene expression of A20 after TNF- $\alpha$ application in Als2 knocked-down neurons (A20 Als2 KD) with respect to control (A20 Als2 Cont.). $(*)$ symbol indicates that $p<0.0001$. 
Als2 transcript, total RNA isolation was performed; followed by qRT-PCR in order to check the Als2 transcript levels. In motor neurons $73.4 \%$ Als2 transcript decrease was observed with respect to the control cells ( $p<0.0001$, Fig. 2a), UXT expression was also measured using the same method. In Als2 knockdown background, UXT expression was found to be decreased by $40 \%$ ( $p<0.0001$ ) (Fig.2b).

Changes of the Expression of NF-KB activated genes when Als2 was downregulated

It is known that UXT is a part of the NF-KB enhancesome complex and it has a role in the activity of NF-KB activated genes such as IL8 and A20. In this study, we used these two genes to address the possible effects of Als2 downregulation on the NF-KB pathway through the changes of UXT expression. In Als2 knocked-down background, IL8 expression was found to be decreased by $84.4 \%(p<0.0001)$ (Fig. 3a). A20 expression was found to be upregulated by $65 \%$ in Als 2 knock-down in spinal motor neurons $(p<0.0001)$ (Fig. 3b).

As an extension of these experiments, $10 \mathrm{ng} / \mathrm{ml} \mathrm{mo-}$ use TNF- $\alpha$ was added to spinal motor neurons in order to see the effect on the NF-KB activated genes in the Als2 knock-down background. Addition of TNF- $\alpha$ reversed the effect of Als2 silencing on IL8 expression (17-fold increase), when compared with the IL8 expression without TNF- $\alpha$ addition ( $p<0.0001$, Fig. $3 c$ ). When Als2 was silenced, A20 expression was found to be increased by $29.5 \%$ in the presence of TNF- $\alpha$ $(p<0.0001$, Fig. 3d).

\section{DISCUSSION}

Although a set of genes responsible for the development of ALS, when mutated, has been described so far, the underlying molecular mechanisms remain to be elucidated ${ }^{15}$.

Als2, one of the causative genes of ALS, encodes a protein, which has several functional domains, but the exact function of this Als 2 protein has not been characterized, yet. Knowing that the Als2 protein interacts with UXT, and UXT is a cofactor in NF-KB enhancesome complex, we designed this study to examine the role of Als2 gene silencing on NF-KB activity in primary spinal motor neurons of mice. To the best of our knowledge silencing of Als2 with RNAi in primary spinal motor neurons isolated from the spinal cord of adult mice has not been studied before. Our data confirm the previous findings that Als2 knockdown directly affects UXT gene expression in our in vitro setting and the downregulation of UXT affects the expressions of two genes in the NF-KB pathway. Interleukin-8 (IL8) expression, as a pro-inflammatory cytokine, decreases during Als2 silencing and this could indicate that the alsin knock-down does not affect an inflammatory response mediated through IL8. On the other hand, the gene expression analysis of A20, a proapoptotic protein involved in NF-KB pathway, reveals that its expression increases significantly when Als2 is silenced. This implies that alsin knock-down would drive the motor neuron to apoptosis via a A20mediated route ${ }^{16-18}$. This could provide a support for the findings of Özdinler et al. where alsin knock-out mice show pathologies in dendrites, soma and organelles in their corticospinal motor neurons and these aberrations make these neurons more vulnerable to death $^{19}$. It is also known that when $A 20$ is induced by NF-KB stimulation, it inhibits canonical NF-KB activation, namely forming a negative feedback control loop. The silencing of Als2 in our study might trigger the $\mathrm{A} 20$ expression via an unknown mechanism to suppress the canonical activation of NF-KB pathway and it may provide a neuroprotective effect to the spinal motor neurons ${ }^{20}$. It should also be noted that the possible pro-apoptotic effect of A20 might be in parallel with the neuroprotective effect, because triggering apoptosis is one of the general protective effects in living organisms to limit the spreading of pathologies.

When TNF- $\alpha$, a well-known NF-KB pathway activator, has been applied, the IL8 expression exhibits a considerable increase ${ }^{21-23}$. However, increase in A20 expression is lower in the presence of TNF- $\alpha$ when it is compared with Als2 knock-down alone. It could 
M.B. Çetin Ozansoy ve M. Ozansoy, Als2 silencing affects the expression of two NF-KB targeted genes via UXT in adult mouse primary spinal motor neuron culture

be concluded from these observations that in the absence of TNF- $\alpha$, silencing of Als 2 alone would lead the motor neurons towards A20-mediated neuronal death. When TNF- $\alpha$ is used, the non-canonical NF$\mathrm{KB}$ pathway is activated through the stimulation of tumor necrosis factor family of receptors (TNFR) ${ }^{24}$. With the activation of this route the possible proapoptotic and/or neuroprotective effect of A20 is overwhelmed by the boosting of IL8 expression and its pro-inflammatory activity.

The involvement of NF-KB pathway within the context of Als2-silenced spinal motor neurons has also to be considered together with the cross-talks among different intracellular signalling pathways. In neuronal cells persistent stimulation of NF-KB induces PI3K/Akt pathway which is a central pro-survival signaling route. In addition, MAPK signalling pathway also interacts with NF-KB pathway. Inhibition of p38 and ERK suppresses the NF-KB transactivation, whereas inhibition of JNK increases NF-KB stimulation via phosphorylation of its $\mathrm{p} 65$ subunit ${ }^{25}$.

All of these data provide a confirmation and elaboration of a connection between alsin, UXT and NF-KB enhancesome complex in the mouse primary spinal motor neuron culture and it may also provide a new starting point in the investigation of mechanisms of motor neuron degeneration in ALS and related disorders ${ }^{26-28}$.

\section{REFERENCES}

1. Ticozzi N, Tiloca C, Morelli C, et al., Genetics of familial Amyotrophic lateral sclerosis, Arch. Ital. Biol. 2011;149(1):6582.

https://doi.org/10.4449/aib.v149i1.1262

2. Al-Chalabi A, Jones A, Troakes C, King A, Al-Sarraj S, van den Berg LH. The genetics and neuropathology of amyotrophic lateral sclerosis, Acta Neuropathol. 2012;124:339-52. https://doi.org/10.1007/s00401-012-1022-4

3. Renton AE, Chio A, Traynor BJ. State of play in amyotrophic lateral sclerosis genetics, Nat. Neurosci. 2014;17:17-23. https://doi.org/10.1038/nn.3584

4. Boillee S, Velde CV, Cleveland DW. ALS: A Disease of Motor Neurons and Their Nonneuronal Neighbors. Neuron. 2006;52:39-59.

https://doi.org/10.1016/j.neuron.2006.09.018

5. Dion PA, Daoud H, Rouleau GA. Genetics of Motor Neuron Disorders: New Insights into Pathogenic Mechanisms, Nat.
Rev. Genet. 2009;10:769-82.

https://doi.org/10.1038/nrg2680

6. Rothstein JD. Current hypotheses for the underlying biology of amyotrophic lateral sclerosis. Ann. Neurol. 2009;65(Suppl. 1):S3-S9. https://doi.org/10.1002/ana.21543

7. Yang $Y$, Hentati A, Deng HX, Dabbagh O, Sasaki T, Hirano $M$, et al. The gene encoding alsin a protein with three guanine-nucleotide exchange factor domains is mutated in a form of recessive amyotrophic lateral sclerosis. Nat. Genet. 2001;29(2):160-5. https://doi.org/10.1038/ng1001-160

8. Hadano S, Mitsui S, Pan L, Otomo A, Kubo M, Sato K, et al. Functional links between SQSTM1 and Als2 in the pathogenesis of ALS: cumulative impact on the protection against mutant SOD1-mediated motor dysfunction in mice, Hum Mol Genet. 2016;25(15):3321-40.

doi: $10.1093 / \mathrm{hmg} / \mathrm{ddw} 180$

https://doi.org/10.1093/hmg/ddw180

9. Hadano S, R. Kunita, A. Otomo, K. Suzuki-Utsunomiya K, Ikeda JE. Molecular and cellular function of ALS2/alsin: implication of membrane dynamics in neuronal development and degeneration. Neurochem. Int. 2007;51:74-84. https://doi.org/10.1016/j.neuint.2007.04.010

10. Chandran J, Ding J, Cai H. Alsin and the molecular pathways of amyotrophic lateral sclerosis. Mol. Neurobiol. 2007;36(3):224-31. https://doi.org/10.1007/s12035-007-0034-x

11. Hadano S, Otomo A, Kunita R, Suzuki-Utsunomiya K, Akatsuka A, Koike $M$ et al. Loss of ALS2/Alsin Exacerbates Motor Dysfunction in a SOD1H46R-Expressing Mouse ALS Model by Disturbing Endolysosomal Trafficking, PLoSOne. 2010; 5(3):120.

https://doi.org/10.1371/journal.pone.0009805

12. Lai C, Xie C, Shim H, Chandran J, Howell BW, Cai H. Regulation of Endosomal Motility and Degradation by Amyotrophic Lateral Sclerosis 2/Alsin. Mol. Brain. 2009;2:23. https://doi.org/10.1186/1756-6606-2-23

13. Cai H, Shim H, Lai C, Xie C, Lin X, Yang WJ et al. ALS2/Alsin Knockout Mice and Motor Neuron Diseases. Neurodegenerative Dis. 2008;5:359-66. https://doi.org/10.1159/000151295

14. Bektaş S, Öztürk G. Enhancement of cultured adult motor neuron survival with cold pre-incubation. Neurosci Lett. 2013;533:23-7. https://doi.org/10.1016/j.neulet.2012.11.013

15. Enunlu I, Ozansoy M, Başak AN. Alfa-Class Prefoldin Protein UXT is a Novel Interacting Partner of Amyotrophic Lateral Sclerosis 2 (Als2) Protein. Biochem. Biophys. Res. Commun. 2011;413(3):471-5. https://doi.org/10.1016/j.bbrc.2011.08.121

16. Schröer A, Schneider S, Ropers HH, Nothwang HG. Cloning and characterization of UXT, a novel gene in human Xp11, which is widely and abundantly expressed in tumor tissue. Genomics. 1999;56(3):340-3. https://doi.org/10.1006/geno.1998.5712

17. Sun S, Tang $Y$, Lou $X$, Zhu L, Yang $K$, Zhang $B$, et al. UXT is a novel and essential cofactor in the NF-kappaB transcriptional enhanceosome. J. Cell. Biol. 2007;178(2):231-44. https://doi.org/10.1083/jcb.200611081

18. Dupuis L, Loeffler JP. Neuromuscular Junction Destruction during Amyotrophic Lateral Sclerosis: Insights from Transgenic Models. Curr. Opin. Pharmacol. 2009;9:341-6. https://doi.org/10.1016/j.coph.2009.03.007 
19. Gautam M, Jara JH, Sekerkove G, Yasvoina MV, Martina M, Özdinler PH. Absence of alsin function leads to corticospinal motor neuron vulnerability via novel disease mechanisms. Hum Mol Genet. 2016;25(6):1074-87.

https://doi.org/10.1093/hmg/ddv631

20. Pujari R, Hunte R, Khan WN, Shembade N. A-20 mediated negative regulation of canonical NF-KB signaling pathway. Immunologic Research. 2013;57(1-3):166-71. https://doi.org/10.1007/s12026-013-8463-2

21. Coornaert B, Carpentier I, Beyaert R. A20: Central Gatekeeper in Inflammation and Immunity. J. Biol. Chem. 2009;284(13):8217-221. https://doi.org/10.1074/jbc.R800032200

22. Beyaert R, Heyninck K, Van Huffel S. A20 and A20-Binding Proteins as Cellular Inhibitors of Nuclear Factor-KB-Dependent Gene Expression and Apoptosis. Biochem. Pharmacol. 2000;60:1143-51. https://doi.org/10.1016/S0006-2952(00)00404-4

23. Shembade N, Parvatiyar K, Harhaj NS, Harhaj EW. The Ubiquitin-Editing Enzyme A20 Requires RNF11 to Downregulate NF-kB Signalling. EMBO J. 2009;28(5):513-22. https://doi.org/10.1038/emboj.2008.285

24. Srinivasan M, Debomoy KH. Significance of NF-KB as a pivotal therapeutic target in the neurodegenerative pathologies of Alzheimer's disease and multiple sclerosis. Expert Opin Ther Targets. 2015;19(4):471-87. https://doi.org/10.1517/14728222.2014.989834

25. Shi ZM, Han YW, Han XH, Zhang K, Chang YN, Hu ZM, et al. J Neurol Sci. 2016;366:127-34. https://doi.org/10.1016/j.jns.2016.05.022

26. Li Q, Spencer NY, Pantazis NJ, Engelhardt JF. Alsin and SOD1G93A Regulate Endosomal ROS Production by Glial Cells and Pro-Inflammatory Pathways Responsible for Neurotoxicity. J. Biol. Chem. 2011;286(46):40151-62. https://doi.org/10.1074/jbc.M111.279711

27. KaltschmidtB, KaltschmidtC. NF-kappaBinthenervoussystem. Cold Spring Harb. Perspect. Biol. 2009;1(3):a001271. https://doi.org/10.1101/cshperspect.a001271

28. Wan F, Lenardo MJ. The Nuclear Signaling of NF-kB: Current Knowledge, New Insights and Future Perspectives. Cell Research. 2010;20:24-33. https://doi.org/10.1038/cr.2009.137 